\title{
Purification of RNA Polymerase from Actinomycin Producing and Nonproducing Cells of Streptomyces antibioticus
}

\author{
GEORGE H. JONES \\ Department of Cellular and Molecular Biology, Division of Biological Sciences, The University \\ of Michigan, Ann Arbor, Michigan 48109
}

Received March 28, 1979; revised May 8, 1979

\begin{abstract}
DNA-dependent RNA polymerase has been purified approximately 700-fold from 12-h-old cells of Streptomyces antibioticus and 400-fold from 48-h cells. Both enzymes appear nearly homogeneous as judged by sodium dodecyl sulfate-polyacrylamide gel electrophoresis. Both enzymes possess subunits corresponding to the $\beta, \beta^{\prime}$, and $\alpha$ subunits of $E$ scherichia coli RNA polymerase but no band corresponding to the $\sigma$ subunit was observed on polyacrylamide gels. Moreover, neither enzyme appears to have $\sigma$ activity as judged by the rifampicin and heparin challenge assays using T4 DNA as template. In addition to the $\beta, \beta^{\prime}$, and $\alpha$ subunits, electrophoresis of the polymerase from 12 -h cells reveals a $45,000 M_{\mathrm{r}}$ protein which is present at a level of $0.40 \mathrm{~mol} / \mathrm{mol}$ of $\beta+\beta^{\prime}$. The polymerases from 12- and 48-h $S$. antibioticus cells differ slightly in their template specificity, with the 48-h polymerase showing a slightly greater preference for calf thymus DNA as compared with several other native DNAs which were tested. Further, the polymerase from 48-h cells was slightly more active with poly (dA-dT) (relative to calf thymus DNA) than was the polymerase from 12-h cells. Neither polymerase was capable of catalyzing actinomycin-resistant transcription.
\end{abstract}

Streptomyces antibioticus is a grampositive actinomycete which produces the antibiotic actinomycin (1). Since actinomycin is a potent inhibitor of DNA-dependent RNA synthesis (2), it is of some biochemical interest to examine the effects of the antibiotic on the producing organism. In previous reports from this laboratory, it was shown that RNA synthesis catalyzed by crude extracts of actinomycin producing $S$. antibioticus cells was less sensitive to inhibition by actinomycin than was synthesis catalyzed by extracts of nonproducing S. antibioticus cells or Escherichia coli cells $(3,4)$. It was further shown that a partially purified RNA polymerase preparation from actinomycin producing $S$. antibioticus cells was capable of catalyzing transcription in the presence of actinomycin concentrations which completely inhibited transcription by $E$. coli RNA polymerase (4). Since the $S$. antibioticus polymerase was not purified to homogeneity, the possibility remained that the ability of the enzyme to catalyze actinomycin-resistant transcription resulted from its association with some accessory factors rather than from some intrinsic differences in the structure of the enzyme as compared with polymerases from other procaryotes. It also seemed possible that differences in the RN $\Lambda$ polymerase from actinomycin producing and nonproducing cells might exist.

Some properties of RNA polymerase from actinomycin producing cells have been reported recently in a preliminary communication from this laboratory (5). In the present report, the details of the purification of RNA polymerase from actinomycin producing and nonproducing cells are presented. These enzymes are compared in terms of subunit structure and stoichiometry and template specificity. The $S$. antibioticus polymerases are further compared with $E$. coli RNA polymerase in terms of subunit composition and actinomycin sensitivity. 


\section{MATERIALS AND METHODS}

\section{Materials}

S. antibioticus cells were grown as described previously (4), and washed with $1 \mathrm{M} \mathrm{KCl}$ in Buffer $\mathrm{A}^{1}$ (see below) prior to polymerase purification. Calf thymus DNA, salnun sperm DNA, $E$. coli DNA, rifampicin, actinomycin $\mathrm{D}$, and phenylmethylsulfonylfluoride were obtained from Sigma. Bacteriophage T4 DNA, poly(dA-dT) and frozen cells of $E$. coli $\mathrm{K}-12$ were from Miles. Polymin $\mathrm{P}$ was from BDH Chemicals, while cellulose powder CF 11 was from Whatman. DNA-cellulose was prepared according to Alberts and Herrick (6). S. antibioticus DNA was prepared as described previously (4). [ $\left.{ }^{3} \mathrm{H}\right] \mathrm{UTP}(45-50 \mathrm{Ci} / \mathrm{mmol})$ was from Amersham. T7 DNA was generously donated by Dr. Michael Chamberlin, University of California, Berkeley.

\section{Buffers}

The basic buffer used throughout the purification contained $10 \mathrm{~mm}$ Tris- $\mathrm{HCl}, \mathrm{pH} 7.8,0.1 \mathrm{~mm}$ potassiumEDTA, 0.1 mM dithiothreitol, $1 \mathrm{~mm}$ phenylmethylsulfonylfluoride (Buffer A), generally also containing $5 \%$ glycerol (Buffer A5).

\section{Miscellaneous Methods}

The RNA polymerase assay was performed as previously described (4) except that each of the four nucleoside triphosphates was present at $0.2 \mathrm{~mm}$. Calf thymus DNA was the template generally used in the polymerase assay. One enzyme unit represents the incorporation of $1 \mathrm{nmol}$ of $\left[{ }^{3} \mathrm{H}\right] \mathrm{UMP}$ into an acid-insoluble form after 10 min of incubation at $30^{\circ} \mathrm{C}$. Assays for RNase and DNase were as previously described (4). Protein was determined by the method of Lowry et al. (7). Sodium dodecyl sulfate (SDS)-polyacrylamide gel electrophoresis was performed according to Laemmli (8) and urea-SDS-polyacrylamide gel electrophoresis by the method of $\mathrm{Wu}$ and Breuning (9) as described by Halling et al. (10). Gels were stained with Coomassie brilliant blue, destained, and scanned at $550 \mathrm{~nm}$ using a Gilford Model 6510-S gel scanner attached to a Model 240 spectrophotometer. A $0.05-\mathrm{mm}$ slit was used to resolve closely spaced protein bands. The relative amounts of the protein present in the gel bands was determined by cutting out and weighing the appropriate peaks from the scanner tracings. Gels containing 2-10 $\mu \mathrm{g}$ of purified polymerase protein were scanned and it was established that within this range, the areas of the subunit peaks were proportional to the amounts of protein applied.

1 Abbreviations used: Buffer A, $10 \mathrm{~mm}$ Tris- $\mathrm{HCl}$, pH 7.8, 0.1 mM potassium-EDTA, 0.1 mM dithiothreitol, $1 \mathrm{mM}$ phenylmethylsulfonylfluoride; Buffer A5, Buffer $A+5 \%$ glycerol; SDS, sodium dodecyl sulfate.

\section{Purification of RNA Polymerase}

The purification procedures are similar to those described by Burgess and Jendrisak (11) for $E$. coli RNA polymerase. All steps were carried out at $0-4^{\circ} \mathrm{C}$.

Step 1. Generally, $50 \mathrm{~g}$ of $12-$ or 48-h S. antibioticus cells was disrupted by yrinding with an equal weight of glass beads in an Omnimixer homogenizer. Cell disruption was accomplished in $100-150 \mathrm{ml}$ of Buffer A5 containing $0.3 \mathrm{M} \mathrm{KCl}$, with homogenization for 4 min in 2-min bursts. The homogenizer cup was immersed in an ice-salt bath during homogenization. The homogenate was then centrifuged for $10 \mathrm{~min}$ at $13,000 \mathrm{~g}$. The supernatant was decanted and the pellet was then homogenized and centrifuged twice more as above using $100-150 \mathrm{ml}$ of buffer each time. The supernatants were combined and denoted "crude extract."

Step 2. RNA polymerase was recovered from the crude extract by precipitation with polyethyleneimine (Polymin P). Polymin P was added from a $10 \%$ stock solution (11) to give a final concentration of $0.33 \%$. The extract was vigorously stirred during Polymin $\mathrm{P}$ addition and stirring was continued for 5 min thereafter. The resulting suspension was then centrifuged for $10 \mathrm{~min}$ at $13,000 \mathrm{~g}$ and the supernatant discarded. The precipitate was extracted with $200 \mathrm{ml}$ of Buffer A5 containing $0.3 \mathrm{M} \mathrm{KCl}$ by homogenizing briefly with a motor-driven Teflon-glass homogenizer. The suspension was centrifuged as above and the supernatant again discarded. RNA polymerase was extracted from the resulting pellet by homogenization in $200 \mathrm{ml}$ of Buffer A5 containing $1.0 \mathrm{M} \mathrm{KCl}$. After centrifugation as above, the pellet was discarded.

Step 3. The $1.0 \mathrm{M} \mathrm{KCl}$ eluate was brought to $50 \%$ saturation with solid ammonium sulfate and the resulting suspension was stirred for $30 \mathrm{~min}$ in the cold. The precipitated protein was collected by centrifugation for $20 \mathrm{~min}$ at $20,000 \mathrm{~g}$. A white, flocculent substance precipitated along with the enzyme at this step, but its presence affected neither the activity of the enzyme nor the subsequent purification steps. The entire precipitate was dissolved in about $100 \mathrm{ml}$ of Buffer A5 and dialyzed overnight against the same buffer.

Step 4. The dialyzed enzyme was applied to a $2 \times 20$ $\mathrm{cm}$ column of DNA-cellulose equilibrated with Buffer A5 containing $0.05 \mathrm{M} \mathrm{KCl}$. The column was washed with Buffer A5 containing 0.10 or $0.15 \mathrm{M} \mathrm{KCl}$ until the $A_{280}$ of the effluent was less than 0.2 and then connected to a $300-\mathrm{ml}$ linear gradient of $0.10-1.10 \mathrm{M} \mathrm{KCl}$ in Buffer A5 for the purification of enzyme from 12-h cells, or to a $350-\mathrm{ml}$ linear gradient of $0.15-1.15 \mathrm{M} \mathrm{KCl}$ for the purification of enzyme from 48 - $h$ cells. The columns were eluted at a flow rate of $50 \mathrm{ml} / \mathrm{h}$. Every third fraction was assayed for polymerase activity. Results of typical columns are shown in Fig. 1. The enzymecontaining fractions $(40-60 \mathrm{ml})$ were pooled and the enzyme was recovered by the addition of solid ammonium sulfate $(50 \mathrm{~g} / 100 \mathrm{ml})$ or by dialysis of the 
pooled fractions against ammonium sulfate $(50 \mathrm{~g} / 100 \mathrm{ml}$ in Buffer A5) without stirring as described by Schrier et al. (12). Ammonium sulfate precipitates were collected as described above and redissolved in a minimal volume of Buffer A5 containing $0.5 \mathrm{M} \mathrm{KCl}$.

Step 5. The concentrated enzyme solution was applied to a $1.6 \times 95-\mathrm{cm}$ column of Bio-Gel A1.5m equilibrated with Buffer A5 containing $0.5 \mathrm{M} \mathrm{KCl}$. Enzymecontaining fractions were pooled and dialyzed overnight against Buffer A containing $50 \%$ glycerol and $0.05 \mathrm{M} \mathrm{KCl}$.

RNA polymerase holoenzyme was prepared from frozen cells of $E$. coli K-12 by Polymin P precipitation and DNA-cellulose chromatography and core enzyme was prepared by chromatography on Bio-Rex 70 as described by Burgess and Jendrisak (11). Spectrophotometric scanning showed that, relative to $\alpha$, the $E$. coli holoenzyme was about $33 \%$ saturated with $\sigma$ factor (see Fig. 2c).

\section{RESULTS}

\section{Purification of RNA Polymerase}

Results of a typical purification of the $S$. antibioticus RNA polymerases are summarized in Table I. The enzyme was generally purified about 700 -fold from 12 -h cells relative to the crude extract, and the yield of enzyme activity varied between 30 and $40 \%$ of that assayed in the crude extract. Approximately 400-fold purification of enzyme from 48 -h cells was routinely obtained

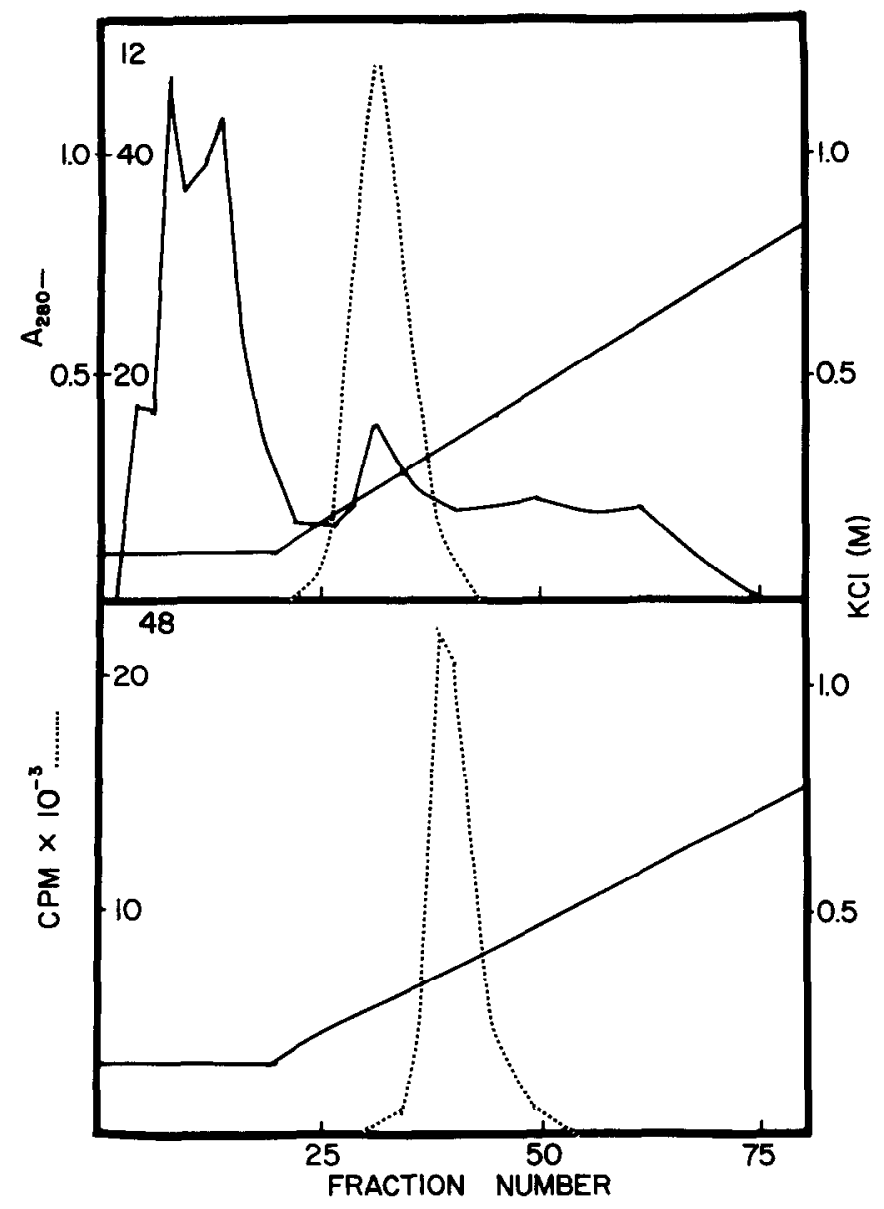

FIG. 1. DNA-cellulose chromatography of $S$. antibioticus RNA polymerase. Dialyzed step 3 enzyme was applied to a $2 \times 20-\mathrm{cm}$ column of DNA-cellulose. The column was eluted with 0.10 or $0.15 \mathrm{M}$ $\mathrm{KCl}$ in Buffer $\mathrm{A} 5$ at $50 \mathrm{ml} / \mathrm{h}$ and 6.4-ml fractions were collected to fraction 20 . The column was then attached to a $300-\mathrm{ml}$ linear gradient of $0.10-1.10 \mathrm{M} \mathrm{KCl}$ in Buffer $\mathrm{A} 5$ for the 12-h enzyme or $0.15-1.15 \mathrm{M} \mathrm{KCl}$ in $350 \mathrm{ml}$ for the 48 -h enzyme, and fractions of $2.7 \mathrm{ml}$ were collected. Fractions 26-40 (12 h) and 35-47 (48 h) were pooled and processed for further purification. 
TABLE I

PURIFICATION of S. antibioticus RNA POLYMERASE ${ }^{a}$

\begin{tabular}{|c|c|c|c|c|c|c|c|c|c|c|c|c|}
\hline \multirow[b]{2}{*}{ Step } & \multicolumn{2}{|c|}{$\begin{array}{l}\text { Volume } \\
\text { (ml) }\end{array}$} & \multicolumn{2}{|c|}{$\begin{array}{l}\text { Protein } \\
\text { (mg) }\end{array}$} & \multicolumn{2}{|c|}{ Units } & \multicolumn{2}{|c|}{$\begin{array}{l}\text { Specific } \\
\text { activity }^{b}\end{array}$} & \multicolumn{2}{|c|}{$\begin{array}{l}\text { Purifica- } \\
\text { tion }\end{array}$} & \multicolumn{2}{|c|}{$\begin{array}{l}\text { Percent- } \\
\text { age yield }\end{array}$} \\
\hline & $12 \mathrm{~h}$ & $48 \mathrm{~h}$ & $12 \mathrm{~h}$ & $48 \mathrm{~h}$ & $12 \mathrm{~h}$ & $48 \mathrm{~h}$ & $12 \mathrm{~h}$ & $48 \mathrm{~h}$ & $12 \mathrm{~h}$ & $48 \mathrm{~h}$ & $12 \mathrm{~h}$ & $48 \mathrm{~h}$ \\
\hline 1 Crude extra & 405 & 287 & 5800 & 3067 & 138 & 145 & 0.02 & 0.05 & - & - & 100 & 100 \\
\hline $2 \mathrm{KCl}$ eluate & 200 & 168 & 584 & 530 & 104 & 84 & 0.18 & 0.16 & 9 & 3.2 & 75 & 58 \\
\hline 3 Ammonium sulfate fraction & 105 & 93 & 316 & 262 & 256 & 240 & 0.81 & 0.92 & 41 & 18.4 & 186 & 166 \\
\hline 4 DNA-cellulose ${ }^{r}$ & 2 & 2.3 & 6.5 & 18 & 70 & 168 & 10.8 & 9.3 & 540 & 186 & 51 & 116 \\
\hline 5 BioGel A $1.5 \mathrm{~m}^{c}$ & 5.6 & 16.6 & 2.9 & 6.8 & 44 & 133 & 15.2 & 19.6 & 760 & 392 & 32 & 92 \\
\hline
\end{tabular}

a Starting from $50 \mathrm{~g}$ of 12 - or 48 -h cells.

${ }^{b}$ Units/mg protein.

c For these fractions activity was measured on concentrated enzyme.

with $85-100 \%$ recovery as compared with crude extracts (5). As reported previously $(4,5)$, purification of the enzyme was generally accompanied by an increase in activity at the intermediate steps (e.g., step 3 of Table I). The yield of enzyme protein varied between 6 and $15 \mathrm{mg} / 100 \mathrm{~g}$ of 12 - or 48 -h cells which is considerably lower than the $50 \mathrm{mg} / 100 \mathrm{~g}$ obtained for $E$. coli (11). In addition, the specific activity of the $S$. antibioticus enzymes is considerably lower than that reported for $E$. coli polymerase (11), in contrast to earlier studies with partially purified $S$. antibioticus RNA polymerase (4). The reason for this discrepancy is unclear, although the stock culture used to

\section{TABLE II}

DEPENDENCE OF $\left[{ }^{3} \mathrm{H}\right]$ UMP INCORPORATION ON SUBSTRATES FOR RNA SYNTHESIS

\begin{tabular}{lcc}
\hline & \multicolumn{2}{c}{$\begin{array}{c}\text { nmol }\left[{ }^{3} \mathrm{H}\right] \text { UMP incorporated } \\
\text { by polymerase from }\end{array}$} \\
\cline { 2 - 3 } \multicolumn{1}{c}{ System } & 12-h cells & 48 -h cells \\
\hline Complete & 0.275 & 0.302 \\
-ATP & 0.006 & 0.008 \\
-GTP & 0.010 & 0.012 \\
- CTP & 0.016 & 0.018 \\
-DNA & 0.004 & 0.004 \\
+RNase $(10 \mu \mathrm{g})$ & 0.008 & 0.012 \\
\hline
\end{tabular}

a The complete system was prepared as described under Materials and Methods. Incubation was for 10 min at $30^{\circ}$. Components were added or omitted as indicated in the table. obtain cells for the present experiments was not the same as that used for the studies reported previously. The specific activity was not considerably increased by the use of DNAs from other sources as templates (see below). It should be noted that Watanabe and Tanaka (13) also found that the RNA polymerase from a rifampicin producing strain of $S$. mediterranei had a specific activity much lower than that of $E$. coli polymerase. Further, it should be noted that the specific activity of the $E$. coli RNA polymerase purified for the studies reported herein was only four- to fivefold greater than the specific activities of the $S$. antibioticus polymerase ( 67 units/mg protein for the $E$. coli enzyme versus $15-20$ units/mg protein (Table I) for the $S$. antibioticus enzymes) under the assay conditions described under Materials and Methods. When poly (dA-dT) was used as template the specific activities were 37.2 units/mg (12-h enzyme), 57.6 units/mg (48-h enzyme), and 191 units/mg ( $E$. coli enzyme). Thus, with this synthetic template, the $E$. coli enzyme was still no more than three- to fivefold more active than the $S$. antibioticus enzymes. It should be noted, however, that the assay conditions used in the present study are not identical to those employed by Burgess and Jendrisak (11). The purified S. antibioticus enzymes were not contaminated with RNase or DNase activities, although DNase was occasionally detected eluting after the polymerase peak from the Bio-Gel column.

Since this report represents the first 
thorough examination of the properties of purified $S$. antibioticus RNA polymerase, it was essential to establish that the enzymes had properties similar to those of other procaryotes. As shown in Table II, incorporation of $\left[{ }^{3} \mathrm{H}\right] \mathrm{UMP}$ into an acid-insoluble form was dependent on the presence of DNA and all four nucleoside triphosphates in reaction mixtures and was abolished by the inclusion of ribonuclease. Magnesium stimulated $\left[{ }^{3} \mathrm{H}\right] \mathrm{UMP}$ incorporation at concentrations of $1-15 \mathrm{~mm}$ and potassium stimulated incorporation at concentrations of 50-150 mM. No difference in cation dependence was observed when polymerases from 12- and 48-h S. antibioticus cells were compared.

\section{Subunit Structure and Stoichiometry of the $S$. antibioticus RNA polymerases}

The subunit structure of the purified polymerases was analyzed by SDS-polyacrylamide gel electrophoresis with or without urea. Figure 2, gels a and b, shows the electrophoretic patterns for the step 5 enzyme from 12 - and 48 -h cells. Some minor bands were visible in gels a and b of Fig. 2, but these were not always observed in other polymerase preparations.

The major bands observable in gels a and b suggest that the $S$. antibioticus RNA polymerase has subunits corresponding to the $\beta, \beta^{\prime}$, and $\alpha$ subunits of $E$. coli RNA polymerase, but no band corresponding to the $\sigma$ subunit was observed on the SDSgels. Further, the $\beta$ and $\beta^{\prime}$ subunits of the $S$. antibioticus RNA polymerase could not be resolved by the Laemmli gel system, whereas the corresponding $E$. coli subunits could be resolved (Fig. 2, gel c). Some separation of the $\beta$ and $\beta^{\prime} S$. antibioticus polymerase subunits was obtained in the urea-SDS system of $\mathrm{Wu}$ and Breuning $((\mathbf{9}$, 10), Fig. 2 , gels d and e). Since the molecular weights of the $\beta$ and $\beta^{\prime}$ subunits have not been conserved in evolution (10), a positive identity has not been assigned to the two protein bands separated on urea-SDS gels. Thus, these two subunits of $S$. antibioticus RNA polymerase will be referred to collectively below as $\beta+\beta^{\prime}$.

Figure 2 , gel a, also shows a $45,000 M_{\mathrm{r}}$ protein (Band $\mathrm{Y}$ ) which is associated with

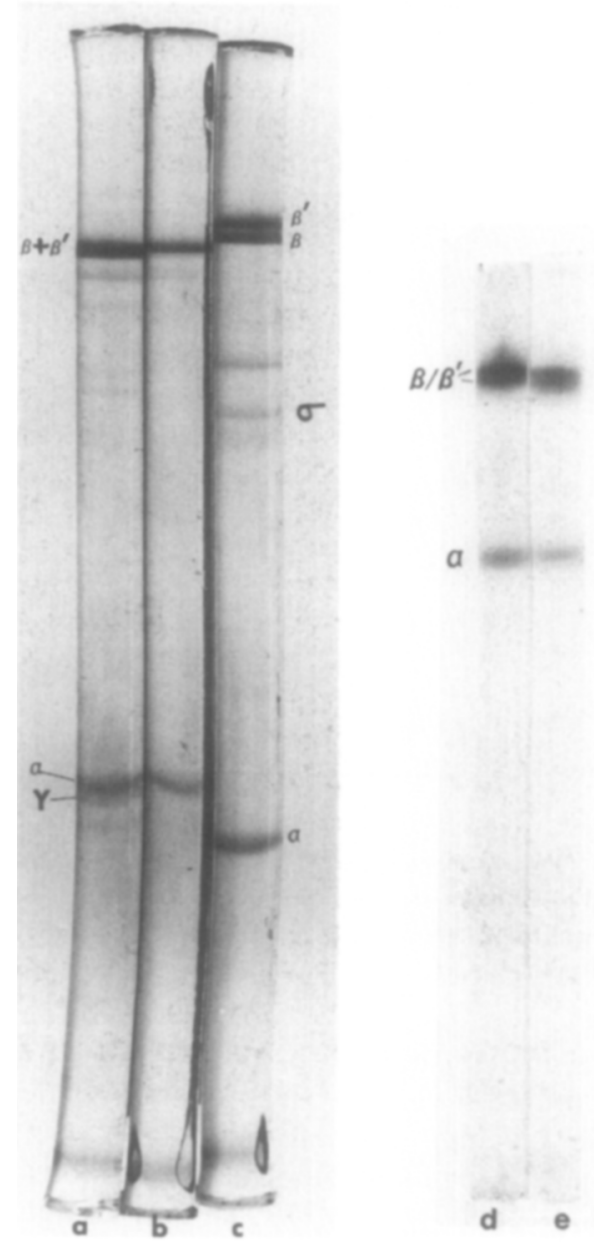

FiG. 2. Polyacrylamide gel electrophoresis of purified polymerases. Gels a and d represent $12-\mathrm{h}$ enzyme (7.5 and $12 \mu \mathrm{g}$, respectively) and gels $\mathrm{b}$ and $\mathrm{e}, 48$-h enzyme ( 4 and $10 \mu \mathrm{g}$, respectively). Gel c depicts $E$. coli holoenzyme $(5 \mu \mathrm{g})$. The acrylamide concentration was $8.7 \%$ in gels a-c which were prepared as described by Laemmli (8). Gels d and e were prepared by the method of Wu and Breuning (9) as described by Halling et al. (10) and the acrylamide concentration was $5 \%$. The following proteins were used as molecular weight markers: the $\beta(155,000), \beta^{\prime}(165,000)$, and $\alpha(39,000)$ subunits of $E$. coli polymerase, $\beta$-galactosidase $(135,000)$, bovine serum albumin $(68,000)$, ovalbumin $(44,000)$, DNase I $(30,000)$, immunoglobulin light chain $(25,000)$, cytochrome $c(13,000)$.

the 12-h polymerase only. A minor band (called X in Ref. (5)) of $145,000 M_{\mathrm{r}}$ is probably an artifact of proteolysis and is not always observed in purified enzyme preparations. Figure 3 represents spectrophotometric 


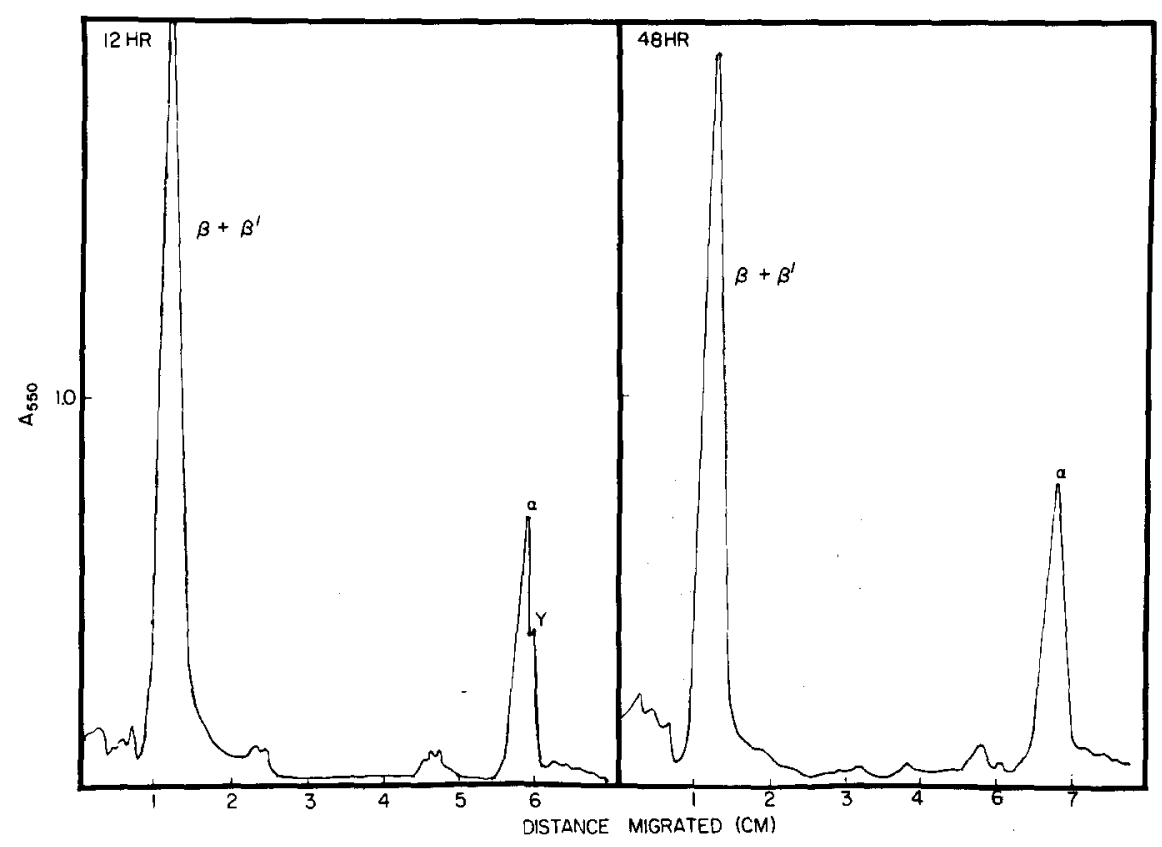

FIG. 3. Densitometric scan of step 5 S. antibioticus RNA polymerase. Gels similar to a and b of Fig. 2 were stained, destained, and scanned as described under Materials and Methods. Scanning was performed using a $0.05-\mathrm{mm}$ slit to allow resolution of the $\alpha$ and $\mathrm{Y}$ bands by the scanning apparatus.

scans of SDS-gels of the polymerases from 12 - and 48 -h cells. It was estimated from these tracings that at least $90 \%$ of the Coomassie brilliant blue reactive materials on these gels represents the $\beta+\beta^{\prime}$ and $\alpha$ bands. $\beta$ and $\beta^{\prime}$ have molecular weights of about 150,000 while $\alpha$ has a molecular weight of about 50,000. Figure 2 clearly shows that the $\alpha$ subunit of the $S$. antibioticus RNA polymerases is larger than the corresponding subunit from $E$. coli polymerase. The corresponding molecular weights for $E$. coli RNA polymerase (11) are $165,000\left(\beta^{\prime}\right), 155,000(\beta)$, and $39,000(\alpha)$.

An estimate of the stoichiometry of the S. antibioticus subunits was made by comparing the areas of the peaks in Fig. 3. To obtain better separation of the $\alpha$ and Y bands, polymerase from 12 -h cells was also electrophoresed on $12.5 \%$ acrylamide gels. Results of a typical analysis are shown in Table III. It can be seen that the molar ratio of $\beta$ or $\beta^{\prime}$ to $\alpha$ (or $\beta+\beta^{\prime}$ to $2 \alpha$ ) is $1: 1$ for both polymerases, while the ratio of $\mathrm{Y}$ to $\beta+\beta^{\prime}$ is $0.40: 1$. These calculations serve to confirm that the $\alpha$ subunit is the $50,000 M_{\mathrm{r}}$ protein in gel a of Fig. 2 and not the $45,000 M_{\mathrm{r}}$ band, since the expected molar ratio of $\beta+\beta^{\prime}$ to $2 \alpha$ is $1: 1$ (14).

\section{Functional Comparisons of RNA Polymerase from 12- and 48- $h S$. antibioticus cells}

It was somewhat surprising to find that neither the polymerase from 12 - nor 48 -h $S$. antibioticus cells possessed a subunit corresponding to $E$. coli $\sigma$, since the purification procedure employed has been reported to yield holoenzyme (11). However, procaryotic polymerase subunits which differ in size but are equivalent in function to $E$. coli $\sigma$ have been reported (15). It thus seemed possible that both the 12 - and 48-h polymerases might possess some $\sigma$ activity. This hypothesis was first tested using the rifampicin challenge assay of Mangel and Chamberlin (16) as described by Amemiya et al. (17). In these experiments, $S$. antibioticus and $E$. col $i$ RNA polymerases were allowed to form binary complexes with T4 DNA at $37^{\circ} \mathrm{C}$ in the absence of nucleoside triphos- 
phates. Nucleoside triphosphates were then added to reaction mixtures alone or simultaneously with rifampicin. Incubation was continued for $10 \mathrm{~min}$ at $37^{\circ} \mathrm{C}$ and RNA synthesis was assayed as described above. Since $\sigma$ activity is required for complex formation $(16,18)$, any RNA synthesis observed in the presence of rifampicin should be due to $\sigma$ induced binding of the RNA polymerase to DNA. Table IV shows that the level of RNA synthesis in the presence of rifampicin was $25 \%$ of that observed in its absence when $E$. coli holoenzyme was the polymerase source. In contrast, essentially no rifampicin-resistant RNA synthesis was observed with $E$. coli core enzyme or either $S$. antibioticus polymerase. The $\mathrm{KCl}$ concentration was $50 \mathrm{mM}$, in these experiments. When the $\mathrm{KCl}$ concentration was increased to $150 \mathrm{mM}$, the percentage of rifampicin-resistant complexes formed in the presence of $E$. coli holoenzyme was decreased, but the level of rifampicin-resistant RNA synthesis catalyzed by the $S$. antibioticus polymerases was not affected (data not shown). These results suggest that rifampicin-resistant transcription of the $\mathrm{T} 4$ DNA is $\sigma$ dependent under the conditions described, and that the S. antibioticus polymerases are present as core rather than holoenzymes. Virtually identical results were obtained with phage T7 DNA except that all the polymerases were more active

TABLE III

Relative Molar Concentrations of RNA POLYMERASE SUbUNITS AND Associated POLYPePtIDES ${ }^{a}$

\begin{tabular}{|c|c|c|c|c|c|c|}
\hline \multirow{2}{*}{$\begin{array}{l}\text { Polymerase } \\
\text { subunit or } \\
\text { polypeptide }\end{array}$} & \multicolumn{2}{|c|}{$\begin{array}{c}\text { Relative } \\
M_{\mathrm{r}}\end{array}$} & \multicolumn{2}{|c|}{$\begin{array}{c}\text { Relative } \\
\text { amount }\end{array}$} & \multicolumn{2}{|c|}{$\begin{array}{l}\text { Relative } \\
\text { molar con- } \\
\text { centration }\end{array}$} \\
\hline & $12 \mathrm{~h}$ & $48 \mathrm{~h}$ & $12 \mathrm{~h}$ & $48 \mathrm{~h}$ & $12 \mathrm{~h}$ & $48 \mathrm{~h}$ \\
\hline$\beta+\beta^{\prime}$ & 0.0 & 3.0 & 2.82 & 2.93 & 0.94 & 0.98 \\
\hline$\alpha$ & 1.0 & 1.0 & 1.0 & 1.0 & 1.0 & 1.0 \\
\hline $\mathrm{Y}$ & 0.92 & - & 0.38 & - & 0.41 & - \\
\hline
\end{tabular}

a The relative amounts of each protein were determined by scanning SDS-polyacrylamide gels as described in the legend to Fig. 3. Molecular weights were assigned using the standards listed in the legend to Fig. 3. Subunit proportions were calculated relative to $\alpha$.
TABLE IV

EFFECTS OF RIFAMPICIN AND HEPARIN ON DNA-RNA Polymerase Complex Formation ${ }^{a}$

\begin{tabular}{lcccc}
\hline & \multicolumn{4}{c}{ nmol $\left[{ }^{3}\right.$ H]UMP incorporated } \\
\cline { 2 - 5 } $\begin{array}{c}\text { Enzyme } \\
\text { used }\end{array}$ & $\begin{array}{c}\text { No } \\
\text { inhibitor }\end{array}$ & $\begin{array}{c}\text { Plus } \\
\text { rifampicin }\end{array}$ & $\begin{array}{c}\text { Plus } \\
\text { heparin }\end{array}$ \\
\hline $12 \mathrm{~h}$ & 0.100 & $0.003(3.0)$ & $0.005(5.0)$ \\
$48 \mathrm{~h}$ & 0.048 & $0.0008(1.6)$ & $0.003(5.6)$ \\
$\begin{array}{l}E . \text { coli } \\
\text { holoenzyme }\end{array}$ & 0.202 & 0.051 & $(25)$ & $0.096(48)$ \\
$\begin{array}{l}E . \text { coli core } \\
48 \text { h step 3 }\end{array}$ & 0.120 & 0.004 & $(3.3)$ & $0.007(5.9)$ \\
& 0.032 & 0.023 & $(71)$ & $0.003(8)$
\end{tabular}

"RNA polymerase $(15-20 \mu \mathrm{g})$ was incubated for 10 min at $37^{\circ} \mathrm{C}$ with $10 \mu \mathrm{g}$ of T4 DNA. Rifampicin $(1 \mu \mathrm{g})$ or heparin $(10 \mu \mathrm{g})$ was then added to selected reaction mixtures. Nucleoside triphosphates were then added and incubation was continued for $10 \mathrm{~min}$ at $37^{\circ} \mathrm{C}$. RNA synthesis was measured as described under Materials and Methods. Values in parentheses represent percentage residual RNA synthesis relative to incubation mixtures lacking rifampicin or heparin.

with this template than with T4 DNA (see Table $\mathrm{V}$, for example). The levels of rifampicin-resistant transcription of T7 DNA were: 12-h enzyme (7.2\%); 48-h enzyme (8.7\%); $E$. coli holoenzyme (42.8\%); $E$. coli core enzyme (7.2\%).

TABLE V

TEMPlate SPECIFICITIES of S. antibioticus RNA POLYMERASES ${ }^{\prime}$

\begin{tabular}{lll}
\hline & \multicolumn{2}{c}{$\begin{array}{c}\text { nmol }\left[{ }^{3} \mathrm{H}\right] \mathrm{U} \text { MP incorporated } \\
\text { by polymerase from }\end{array}$} \\
\cline { 2 - 3 } \multicolumn{1}{c}{ Template } & 12-h cells & 48 -h cells \\
\hline Calf thymus DNA & $0.233(100)$ & $0.252(100)$ \\
S. antibioticus DNA & $0.042(18)$ & $0.042(17)$ \\
E. coli DNA & $0.107(46)$ & $0.098(39)$ \\
Micrococcus & & \\
$\quad$ lysodeikticus DNA & $0.032(14)$ & $0.024(10)$ \\
T4 DNA & $0.143(61)$ & $0.120(48)$ \\
poly(dA-dt) & $0.570(245)$ & $0.740(294)$ \\
T7 DNA & $0.379(163)$ & $0.259(103)$ \\
\end{tabular}

${ }^{a}$ Reaction mixtures contained $10 \mu \mathrm{g}$ of template and $10 \mu \mathrm{g}$ of RNA polymerase in $100 \mu \mathrm{l}$. Values in parentheses represent template activity relative to calf thymus DNA, set arbitrarily at $100 \%$ activity. 


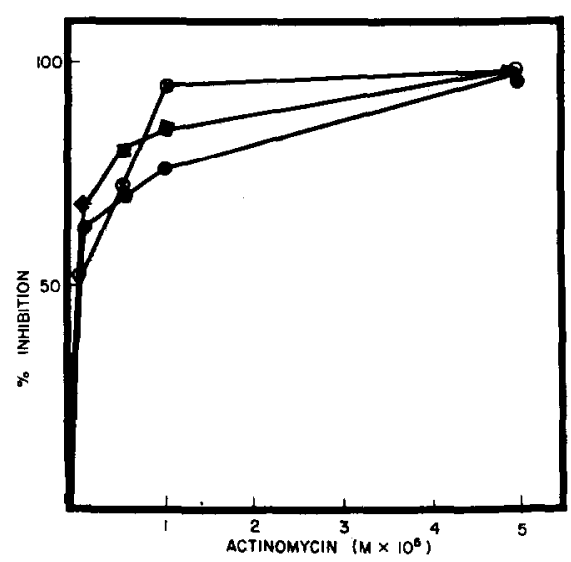

FIG. 4. Effects of actinomycin on transcription of $S$, antibioticus DNA by $E$. coli and $S$. antibioticus RNA polymerases. Reaction mixtures contained about $15 \mu \mathrm{g}$ of RNA polymerase. Results are expressed as percentage inhibition of $\left[{ }^{3} \mathrm{H}\right] \mathrm{UMP}$ incorporation by actinomycin using $0.15 \mathrm{mg}$ of DNA as template. The filled circles represent transeription by 12 - or $48-\mathrm{hr}$ S. antibioticus polymerases both of which showed an essentially identical response to actinomycin. The squares represent transcription by $E$. coli holoenzyme and the open circles represent transcription by $E$. coli core enzyme.

These results were supported by similar experiments (again at $50 \mathrm{mM} \mathrm{KCl}$ ) in which polymerase-DNA complexes were challenged with heparin. Significant levels of heparin-resistant RNA synthesis were catalyzed by $E$. coli holoenzyme but not by core enzyme or $S$. antibioticus polymerase (Table IV). Table IV also shows that step 3 polymerase from 48-h $S$. antibioticus cells catalyzed RNA synthesis which was quite resistant to rifampicin but which was sensitive to heparin. This result was consistently observed with T4 DNA.

As shown in Table $\mathrm{V}$, the enzymes from 12- and 48-h S. antibioticus cells also differed in their template specificities. Relative to enzyme from 12-h cells, the enzyme from 48-h S. antibioticus cells showed a slight preference for calf thymus DNA as compared with several other native DNAs which were tested. Table $\mathrm{V}$ also shows that the polymerase from 48 -h $S$. antibioticus cells was slightly more active with poly (dAdT) as template (relative to calf thymus DNA) than was the polymerase from $12-h$ cells.

\section{Actinomycin Sensitivity of Transcription by Purified Polymerases}

As reported previously (4), a partially purified $S$. antibioticus RNA polymerase preparation catalyzed transcription at actinomycin concentrations which inhibited transcription by $E$. coli RNA polymerase. One goal of the studies presented in the prcsent report was to determine whether highly purified $S$. antibioticus polymerase retained this property. In Fig. 4, the effects of actinomycin on transcription of $S$. antibioticus DNA by $S$. antibioticus and $E$. coli polymerases are shown. In contrast to the results obtained with crude $S$. antibioticus extracts and partially purified RNA polymerase, there was little difference in the actinomycin sensitivity of transcription catalyzed by $S$. antibioticus polymerase as compared with the $E$. coli enzyme (Fig. 4). With both enzymes, a given concentration of actinomycin inhibited transcription of $S$. antibioticus DNA to a somewhat greater extent than transcription of calf thymus DNA (data not shown). The data of Fig. 4 further show that the pattern of actinomycin inhibition was essentially the same whether enzyme from 12- or 48-h $S$. antibioticus cells was employed. These data suggest that the previous observation of actinomycinresistant transcription by crude extracts and by partially purified $S$. antibioticus RNA polymerase was not attributable to an intrinsic property of the enzyme itself.

\section{DISCUSSION}

The results presented in this paper and the earlier preliminary communication (5) represent the first reports of the purification of RNA polymerase from Streptomyces antibioticus. These studies show that the $S$. antibioticus polymerases have properties which are similar to those of other grampositive and gram-negative bacteria. Like the polymerases of certain Bacilli $(10,19$, 20 ), the $\beta^{\prime}$ and $\beta$ subunits of the $S$. antibioticus polymerase have very similar molecular weights and cannot easily be resolved on SDS-gels. The S. antibioticus polymerases appear to be unlike both the Bacillus and $E$. coli polymerases, however, in the size of the $\alpha$ subunit. Figure 2 above 
clearly shows that the $\alpha$ subunit of the $S$. antibioticus polymerases is considerably larger than the corresponding subunit from E. coli.

It is noteworthy that the S. antibioticus RNA polymerases do not possess a subunit which corresponds to $E$. coli $\sigma$, and some RNA polymerases have been shown to possess a $\sigma$ factor which has a molecular weight between 40 and 50,000 (15). Although the polymerase from 12 -h cells is associated with a $45,000 M_{\mathrm{r}}$ protein it seems unlikely that this protein represents $S$. antibioticus $\sigma$ since polymerase from 12 -h cells showed no $\sigma$ dependent synthetic activity in the rifampicin or heparin challenge assays with T4 DNA as template (Table IV). Indeed, the $S$. antibioticus polymerase was no more active than $E$. coli core polymerase in these assays. It might be argued that the 45,000 $M_{\mathrm{r}}$ protein is actually the $\alpha$ subunit of $S$. antibioticus RNA polymerase. However, when 12 - and 48-h polymerases were electrophoresed together, the 50,000 and 45,000 $M_{\mathrm{r}}$ bands were still resolved and the staining intensity of the $50,000 M_{\mathrm{r}}$ band increased while that of the $45,000 M_{\mathrm{r}}$ band was the same as when 12 -h polymerase alone was subjected to electrophoresis. Thus the 45,000 $M_{\mathrm{r}}$ band does not seem to correspond to either the $\sigma$ or the $\alpha$ proteins of $E$. coli. In summary, then, the structural and functional studies suggest, but certainly do not prove, that the $S$. antibioticus enzymes represent core polymerases. With reference to the challenge assays, however, it must be kept in mind that neither T4 nor T7 DNAs are homologous templates for $S$. antibioticus polymerases. It is possible that the use of homologous phage templates might reveal the presence of $\sigma$ activity in the purified polymerase preparations. To date, however, such templates have not been available for activity studies.

The question thus remains, what is the nature of $S$. antibioticus $\sigma$ factor? Although the purification procedure employed in this study can be used to prepare holoenzyme from $E$. coli, only enzymes apparently representing core polymerase have been obtained from $S$. antibioticus cells. No evidence for multiple polymerase forms has ever been observed on DNA-cellulose or
Bio-Gel chromatograms. Thus, the nature of the $S$. antibioticus $\sigma$ factor cannot be definitively established at this time, but the situation could be analogous to that observed in sporulating $B$. subtilis. In those cells, it can be shown that $\sigma$ activity, though present, is prevented from associating with the core polymerase. Thus, the polymerase purified from these cells is nearly devoid of $\sigma$ activity even though normal amounts of the protein are present in the cells (20). Since $\sigma$ can function catalytically (18), it seems possible that the $S$. antibioticus polymerase might associate with small amounts of $\sigma$ protein "in vivo" to permit gene transcription to take place. The results of the rifampicin challenge experiments with 48-h step 3 enzyme (Table IV) at least suggest that active $\sigma$ does exist in $S$. antibioticus cells.

The data of Fig. 4 indicate that step 5 $S$. antibioticus RNA polymerase has lost the ability to catalyze actinomycin-resistant transcription which was observed with crude cell extracts and partially purified enzyme (4). This finding suggests that some substances are removed during the purification which are responsible for this property. If this interpretation is correct, one would predict that the sensitivity of transcription to actinomycin inhibition would increase as more highly purified polymerase preparations were used. This is, in fact, what is observed. In a previous report, for example, it was shown that $50 \mu \mathrm{M}$ actinomycin inhibited RNA synthesis catalyzed by a crude extract of 48 -h $S$. antibioticus cells by $15 \%$ and synthesis catalyzed by a 110 -fold purified enzyme by about $50 \%$, with $S$. antibioticus DNA as template (4). In the present studies, this actinomycin concentration inhibited $\left[{ }^{3} \mathrm{H}\right] \mathrm{UMP}$ incorporation by $12 \%$ when crude extract was the polymerase source and $S$. antibioticus DNA the template and by $43 \%$ when step 3 enzyme was the polymerase source (data not shown). As can be seen in Fig. 4, transcription of $S$. antibioticus DNA by highly purified $S$. antibioticus RNA polymerase was inhibited by greater than $95 \%$ at $50 \mu \mathrm{M}$ actinomycin. Thus, the ability to catalyze actinomycin-resistant transeription is certainly not an intrinsic property of the $S$. antibioticus core poly- 
merase. Experiments are in progress to isolate substances conferring actinomycin resistance from $S$. antibioticus cell extracts. To date, no evidence for enzymes in S. antibioticus cells which degrade actinomycin has been found.

\section{ACKNOWLEDGMENT}

This research was supported by Grant 5R01CA1275206 from the National Cancer Institute, U. S. Public Health Service.

\section{REFERENCES}

1. Waksman, S. A. (1968) Actinomycin-Nature, Formation and Activities, Wiley-Interscience, New York.

2. Reich, E., AND Goldberg, I. H. (1964) Progr. Nucleic Acids Res. 3, 183-234.

3. JoNES, G. H. (1975) Biochem. Biophys. Res. Commun. 63, 469-475.

4. JONES, G. H. (1976) Biochemistry 15, 3331-3341.

5. Jones, G. H. (1978) Biochem. Biophys. Res. Commun. 84, 462-468.

6. Alberts, B., AND Herrick, G. (1971) in Methods in Enzymology (Grossman, L., ed.), Vol. 21, pp. 198-217, Academic Press, New York.

7. Lowry, O. H., Rosebrough, N. J., Farr, A. L., and Randall, R. J. (1951) J. Biol. Chem. 193, 265-275.
8. LAEmmLI, U. K. (1970) Nature (London) 227, 680-685.

9. WU, G.-J., AND Breuning, G. E. (1971)Virology 46, 596-612.

10. Halling, S.M., BukTis, K. C., ANd Doi, R. H. (1977) J. Biol. Chem. 252, 9024-9031.

11. Burgess, R. R., AND JENDRISAK, J. J. (1975) Biochemistry 14, 4634-4638,

12. Schrier, M. H., Erni, B., and Staehlin, T. (1977) J. Mol. Biol. 116, 727-753.

13. Watanabe, S., and Tanaka, K. (1976) Biochem. Biophys. Res. Commun. 72, 522-529.

14. Burgess, R. R. (1969) J. Biol. Chem. 244, $6168-6176$.

15. Burgess, R. R. (1976) in RNA Polymerase (Chamberlin, M., and Losick, R., eds.), pp. 69-100, Cold Spring Laboratory, Cold Spring Harbor, N. Y.

16. Mangel, W. F., and Chamberlin, M. (1974) $J$. Biol. Chem. 249, 2995-3001.

17. AmemiYa, K., Wu, C. W., AND Shapiro,L. (1977) J. Biol. Chem. 252, 4157-4165.

18. Travers, A. A., AND Burgess, R. R. (1969) Nature (London) 222, 537-540.

19. LinN, T. G., Greenleaf, A. A., Shorenstein, R. G., AND Losick, R. (1973) Proc. Nat. Acad. Sci. USA 70, 1865-1869.

20. Losick, R., AND Pero, J. (1976) in RNA Polymerase (Chamberline, M. and Losick, R., eds.), pp. 227-246, Cold Spring Harbor Laboratory, Cold Spring Harbor, N. Y. 